\title{
ANALISIS MAKROEKONOMI YANG MEMPENGARUHI LIKUIDITAS PASAR DAN HARGA SAHAM INDEX CONSUMER GOODS BURSA EFEK INDONESIA SELAMA TAHUN 2017
}

\author{
Sri Retnaning Sampurnaningsih ${ }^{1)}$
}

1) dosen universitas pamulang, email : niningsampoerna@yahoo.co.id

\section{ARTICLES}

INFORMATION

ABSTRACT

\section{JURNAL SEKURITAS \\ (Saham, Ekonomi, Keuangan dan Investasi ) \\ Vol.1, No.4, Juni 2018 \\ Halaman : $24-37$ \\ C LPPM \& Prodi Manajemen \\ UNIVERSITAS PAMULANG \\ ISSN (online) : 2581-2777 \\ ISSN (print) : :2581-2696}

\section{Keyword :}

Likuditas Pasar Harga

Saham BI Rate, Inflasi, Kurs Rupiah.

JEL. classification : C31, E50

\section{Contact Author :}

PRODI MANAJEMEN UNPAM

JL.Surya Kencana No.1 Pamulang

Tangerang Selatan - Banten

Telp. (021) 7412566, Fax (021) 7412491 Email :

jurnalfinance.unpam@gmail.com
Telah dilakukan penelitian dengan judul Analisis Penelitian bertujuan untuk membuktikan secara empirik pengaruh BI Rate, Inflasi dan Kurs Rupiah secara parsial maupun bersama-sama terhadap Volume Perdagangan Saham Index Consumer Goods. Metode yang digunakan dalam penelitian adalah Least Square Methods dengan dua variable dependen. Data yang digunakan dalam penelitian diperoleh dari Bursa Efek Indonesia dan Bank Indonesia, kemudian diambil 235 sampel selama tahun 2017 untuk diuji. Data penelitian diolah menggunakan software Eviews 9. Hasil dari penelitian dapat disimpulkan bahwa BI Rate tidak berpengaruh terhadap Volume Perdagangan Saham Index Consumer Goods, Inflasi tidak berpengaruh terhadap Volume Perdagangan Saham Index Consumer Goods, Kurs Rupiah berpengaruh signifikan terhadap Volume Perdagangan Saham Index Consumer Goods. BI Rate, Inflasi dan Kurs Rupiah secara bersama-sama berpengaruh sangat signifikan terhadap Volume Perdagangan Saham Index Consumer Goods. BI Rate berpengaruh sangat signifikan terhadap Harga Saham Index Consumer Goods. Inflasi berpengaruh sangat signifikan terhadap Harga Saham Index Consumer Goods. Kurs Rupiah berpengaruh sangat signifikan terhadap Harga Saham Index Consumer Goods. BI Rate, Inflasi dan Kurs Rupiah secara bersama-sama berpengaruh sangat signifikan terhadap Harga Saham Index Consumer Goods.

The research aims to prove empirically the influence of $B I$ Rate, Inflation and Rupiah exchange partially or jointly to Stock Trading Volume Consumer Index Goods. The method used in this research is Least Square Methods with two dependent variables. The data used in the study were obtained from the Indonesia Stock Exchange and Bank Indonesia, then taken 235 samples during 2017 to be tested. The research data is processed by using Eviews 9 software. The result of this research can be concluded that the BI Rate has no effect on the Trading Volume of Consumer Goods Index, Inflation does not affect the Trading Volume of Consumer Goods Index, the Rupiah exchange rate has significant effect to the Trading Volume Consumer Goods Index. The BI Rate, Inflation and Rupiah Exchange Rate together have a very significant effect on the Index of Consumer Goods Stock Trading Volume. The BI Rate has a very significant effect on the Consumer Goods Index's Stock Price. Inflation has a very significant effect on Consumer Goods Index Stock Price. The Rupiah exchange rate has a very significant effect on the Consumer Goods Index's Stock Price. BI Rate, Inflation and Rupiah Exchange Rate together have a very significant effect on Consumer Goods Index Stock Price. 


\section{A. Pendahuluan}

Pasar modal merupakan pertemuan antara pihak yang memiliki kelebihan dana dengan pihak yang membutuhkan dana dengan cara memperjualbelikan sekuritas. Pasar modal juga bisa diartikan sebagai pasar untuk memperjualbelikan sekuritas yang umumnya memiliki umur lebih dari satu tahun, seperti saham dan obligasi. Sedangkan tempat di mana terjadinya jual-beli sekuritas disebut dengan bursa efek (Eduardus, 2010). Di dalam pasar modal terdapat indeks-indeks saham yang merupakan pengelompokan saham berdasarkan kriteria tertentu. Indeks Harga Saham adalah nilai dari sekelompok saham yang dikumpukan berdasarkan kategori tertentu. Indeks harga saham merupakan indikator atau cerminan pergerakan harga saham.Indeks merupakan salah satu pedoman bagi investor untuk melakukan investasi di pasar modal, khususnya saham (Jogiyanto, 2013). Salah satu indeks yang ada di Bursa Efek Indonesia Indeks Sektoral. Indeks ini adalah bagian dari IHSG, pertama kali diperkenalkan pada tanggal 2 Januari 1996 dengan nilai awal indeks adalah 100 untuk masing-masing sektor, menggunakan hari dasar tanggal 28 Desember 1995. Menggunakan semua Perusahaan Tercatat yang termasuk dalam masing-masing sektor. Indeks sektoral ini terbagi ke dalam 10 sektor yang ada di BEl yaitu; sektor Pertanian (Agriculture), Pertambangan (Mining), Industri Dasar (Basic Industry), Aneka Industri (Miscellaneous Industry), Barang Konsumsi (Consumer Goods), Property, Infrastruktur, Keuangan (Finance), Perdangangan dan Jasa (Trade) dan Manufatur.

Dalam kesempatan ini peneliti mencoba mengkaji pengaruh makroekonomi terhadap likuiditas perdagangan saham dan Harga saham (Harga Saham) salah satu indeks sektoral Bursa Efek Indonesia, yaitu Indeks Barang Konsumsi (Consumer Goods). Adapun yang menjadi variable independen penelitian yaitu BI Rate, Inflasi dan Kurs Rupiah. Sedangkan variable dependen penelitian adalah Likuiditas perdagangan saham yang diproxikan oleh Volume Perdagangan dengan satuan Lot. Kemudian yang menjadi variable dependen berikutnya adalah Harga saham.

\section{B. Perumusan Masalah}

Perumusan masalah dalam penelitian yaitu

1. Apakah BI Rate mempengaruhi Volume Perdagangan Saham Index Consumer Goods?

2. Apakah Inflasi mempengaruhi Volume Perdagangan Saham Index Consumer Goods?

3. Apakah Kurs Rupiah mempengaruhi Volume Perdagangan Saham Index Consumer Goods ?

4. Apakah BI Rate, Inflasi dan Kurs Rupiah secara bersama-sama mempengaruhi Volume Perdagangan Saham Index Consumer Goods?

5. Apakah BI Rate mempengaruhi Harga Saham Index Consumer Goods ?

6. Apakah Inflasi mempengaruhi Harga Saham Index Consumer Goods ?

7. Apakah Kurs Rupiah mempengaruhi Harga saham Index Consumer Goods ?

8. Apakah BI Rate, Inflasi dan Kurs Rupiah secara bersama-sama mempengaruhi Harga saham Index Consumer Goods? 


\section{Tujuan Penelitian}

Penilitian bertujuan untuk

1. Membuktikan secara empirik pengaruh BI Rate terhadap Volume Perdagangan Saham Index Consumer Goods

2. Membuktikan secara empirik pengaruh Inflasi terhadap Volume Perdagangan Saham Index Consumer Goods

3. Membuktikan secara empirik pengaruh Kurs Rupiah terhadap Volume Perdagangan Saham Index Consumer Goods

4. Membuktikan secara empirik pengaruh BI Rate, Inflasi dan Kurs Rupiah secara bersama-sama terhadap Volume Perdagangan Saham Index Consumer Goods

5. Membuktikan secara empirik pengaruh BI Rate terhadap Harga Saham Index Consumer Goods

6. Membuktikan secara empirik pengaruh Inflasi terhadap Harga Saham Index Consumer Goods

7. Membuktikan secara empirik pengaruh Kurs Rupiah terhadap Harga Saham Index Consumer Goods

8. Membuktikan secara empirik pengaruh BI Rate, Inflasi dan Kurs Rupiah secara bersama-sama terhadap Harga Saham Index Consumer Goods

\section{Landasan Teori}

\section{Arbitrage Pricing Theory}

Arbitrage Pricing Theory pertama kali dikembangkan oleh Stephen Ross (1976). Teorinya diawali dengan analisis tentang bagaimana investor membangun portofolio yang efisien dan menawarkan pendekatan baru untuk menjelaskan harga aset dan menyatakan bahwa pengembalian atas aset berisiko adalah kombinasi linier dari berbagai faktor makroekonomi yang tidak dijelaskan oleh teori ini. Mirip dengan CAPM, diasumsikan bahwa investor sepenuhnya terdiversifikasi dan risiko sistematis merupakan faktor yang mempengaruhi dalam jangka panjang. Namun, tidak seperti model CAPM, APT menentukan hubungan linier sederhana antara pengembalian aset dan faktor terkait karena masing-masing saham atau portofolio memiliki serangkaian faktor risiko dan tingkat kepekaan yang berbeda terhadap masing-masing faktor. Teori APT menyatakan bahwa sejumlah faktor yang berbeda menentukan return pasar. Roll dan Ross menyatakan bahwa pengembalian jangka panjang keamanan adalah fungsi dari perubahan: Inflasi, Produksi industry, Premi risiko, kemiringan struktur suku bunga. Selanjutnya teori ini dikembangkan lagi oleh Chen, Roll dan Ross (1986), mengidentifikasi empat faktor yang mempengaruhi return sekuritas, yaitu: Perubahan tingkat inflasi, perubahan produksi industri yang tidak diantisipasi, perubahan premi risk-default yang tidak diantisipasi, perubahan struktur tingkat suku bunga yang tidak diantisipasi.

\section{Likuditas Pasar Saham}

Beberapa penelitian yang pernah dilakukan mengenai likuiditas pasar diantaranya yaitu Woon Gyu Choi, David Cook (2005) Di pasar keuangan yang likuid, investor 
dapat menjual blok aset yang besar tanpa mengubah harga secara substansial. Hasil penelitian mendokumentasikan penurunan tajam likuiditas pasar saham Jepang pada periode pasca-bubble dan peningkatan risiko likuiditas yang tajam. selama periode deflasi Jepang, perusahaan dengan neraca likuid lebih sedikit terpapar risiko likuiditas pasar saham, sementara perusahaan yang tumbuh perlahan sangat terpapar guncangan likuiditas. Juga, likuiditas agregat memiliki efek makroekonomi terhadap permintaan agregat melalui pengaruhnya terhadap permintaan uang. Penelitian mengenai faktor-faktor yang mempengaruhi volume perdagangan saham juga pernah dilakukan oleh Bambang Widjanarko Otok, Suryo Guritno dan Subanar (2006), dimana dalam hasil penelitiannya IHSG, Kurs Dollar, Right Issue dan SIBOR secara parsial berpengaruh signifikan terhadap volume perdagangan saham. Penelitian lainnya mengenai variable makroekonomi yang mempengaruhi likuditas pasar saham dilakukan oleh Rasmiah Ahmad Abu Mousa (2016) Tujuan dari penelitian ini adalah untuk mengetahui hubungan antara variabel makroekonomi yang dipilih: money supply, nilai tukar (\$ / JOD), suku bunga deposito berjangka dan tabungan, indeks harga konsumen, tingkat pengangguran dan produk domestik bruto (PDB) terhadap likuiditas Amman Stock Exchange (ASE).

\section{E. Metodologi}

Objek dalam penelitian yaitu Index Consumer Goods PT. Bursa Efek Indonesia yang beralamat di Jakarta. Pengamatan dilakukan pada tanggal 3 Januari 2017 sampai dengan 29 Desember 2017. Penelitian ini secara khusus menganalisis variable makroekonomi terhadap likuiditas (Volume) Perdagangan Saham dan Harga saham Index Consumer Goods selama tahun 2017.

Teknik pengambilan sampel dalam penelitian ini menggunakan nonprobability purposive sampling, dimana sampel yang diambil dari populasi ditentukan berdasarkan pertimbangan tertentu (Sugiyono, 2013). Data Penelitian ini yang digunakan adalah data harian menggunakan 235 sampel untuk masing-masing variable independen maupun dependen. Data penelitian yang diambil merupakan data sekunder yang peroleh dari Bank Indonesia (www.bi.go.id), Bursa Efek Indonesia (www.idx.co.id) dan dari www.duniainvestasi.com. Metode analisis yang digunakan dalam penelitian ini adalah Least Squares Method dan data diolah menggunakan Eviews 9 (Bambang dan Junaidi, 2012), (Gujarati, 2010)

\section{F. Hasil dan Pembahasan}

Hasil penelitian berdasarkan data yang diperoleh diuraikan pada tabel berikut Tabel. Data Variabel Hasil Penelitian

$\begin{array}{rcrlrrr}\text { No. } & \text { Date } & \text { BI Rate } & \text { Inflasi } & \begin{array}{c}\text { Kurs } \\ \text { Rupiah }\end{array} & \begin{array}{l}\text { Harga } \\ \text { Saham }\end{array} & \text { Volume } \\ 1 & 29-12-2017 & 0.0425 & 0.0361 & 13548 & 2,861.39 & 1,691,491,071,438 \\ 2 & 28-12-2017 & 0.0425 & 0.0361 & 13560 & 2,835.26 & 1,772,399,653,093 \\ 3 & 27-12-2017 & 0.0425 & 0.0361 & 13562 & 2,826.84 & 2,415,019,923,053\end{array}$




\begin{tabular}{|c|c|c|c|c|c|c|}
\hline 4 & $22-12-2017$ & 0.0425 & 0.0361 & 13558 & $2,811.74$ & $994,875,213,865$ \\
\hline 5 & $21-12-2017$ & 0.0425 & 0.0361 & 13545 & $2,789.41$ & $1,561,434,942,725$ \\
\hline 6 & $20-12-2017$ & 0.0425 & 0.0361 & 13579 & $2,734.89$ & $965,265,372,895$ \\
\hline 7 & $19-12-2017$ & 0.0425 & 0.0361 & 13587 & $2,776.91$ & $1,289,905,492,380$ \\
\hline 8 & $18-12-2017$ & 0.0425 & 0.0361 & 13584 & $2,743.35$ & $951,471,166,266$ \\
\hline 9 & $15-12-2017$ & 0.0425 & 0.0361 & 13573 & $2,705.37$ & $1,173,331,124,550$ \\
\hline 10 & 14-12-2017 & 0.0425 & 0.0361 & 13565 & $2,680.65$ & $1,537,309,056,825$ \\
\hline 11 & 13-12-2017 & 0.0425 & 0.0361 & 13589 & $2,664.88$ & $624,938,506,689$ \\
\hline 12 & $12 / 12 / 2017$ & 0.0425 & 0.0361 & 13550 & $2,667.62$ & $664,064,443,745$ \\
\hline 13 & $11 / 12 / 2017$ & 0.0425 & 0.0361 & 13546 & $2,668.39$ & $635,336,670,420$ \\
\hline 14 & 8/12/2017 & 0.0425 & 0.0361 & 13556 & $2,663.72$ & $1,097,772,157,430$ \\
\hline 15 & $7 / 12 / 2017$ & 0.0425 & 0.0361 & 13552 & $2,640.06$ & $570,852,177,495$ \\
\hline 16 & $6 / 12 / 2017$ & 0.0425 & 0.0361 & 13524 & $2,644.83$ & $581,438,794,375$ \\
\hline 17 & $5 / 12 / 2017$ & 0.0425 & 0.0361 & 13515 & $2,634.85$ & $755,224,666,068$ \\
\hline 18 & $4 / 12 / 2017$ & 0.0425 & 0.0361 & 13527 & $2,621.12$ & $822,991,148,721$ \\
\hline 19 & 30-11-2017 & 0.0425 & 0.0330 & 13514 & $2,560.28$ & $1,923,560,340,340$ \\
\hline 20 & 29-11-2017 & 0.0425 & 0.0330 & 13515 & $2,644.68$ & $887,756,043,525$ \\
\hline 21 & $28-11-2017$ & 0.0425 & 0.0330 & 13527 & $2,664.49$ & $1,141,341,878,275$ \\
\hline 22 & 27-11-2017 & 0.0425 & 0.0330 & 13511 & $2,627.06$ & $698,857,305,375$ \\
\hline 23 & $24-11-2017$ & 0.0425 & 0.0330 & 13506 & $2,596.58$ & $716,149,420,400$ \\
\hline 24 & 23-11-2017 & 0.0425 & 0.0330 & 13503 & $2,585.25$ & $517,640,698,638$ \\
\hline 25 & 22-11-2017 & 0.0425 & 0.0330 & 13523 & $2,592.30$ & $691,718,115,550$ \\
\hline 26 & 21-11-2017 & 0.0425 & 0.0330 & 13544 & $2,612.62$ & $661,010,393,863$ \\
\hline 27 & 20-11-2017 & 0.0425 & 0.0330 & 13529 & $2,610.10$ & $661,646,925,525$ \\
\hline 28 & $17-11-2017$ & 0.0425 & 0.0330 & 13517 & $2,594.79$ & $831,549,795,050$ \\
\hline 29 & $16-11-2017$ & 0.0425 & 0.0330 & 13538 & $2,625.40$ & $927,409,785,422$ \\
\hline 30 & $15-11-2017$ & 0.0425 & 0.0330 & 13539 & $2,559.08$ & $1,025,311,739,643$ \\
\hline 31 & $14-11-2017$ & 0.0425 & 0.0330 & 13542 & $2,561.53$ & $813,260,759,875$ \\
\hline 32 & $13-11-2017$ & 0.0425 & 0.0330 & 13555 & $2,587.59$ & $679,830,822,075$ \\
\hline 33 & $10 / 11 / 2017$ & 0.0425 & 0.0330 & 13514 & $2,563.49$ & $824,698,649,275$ \\
\hline 34 & 9/11/2017 & 0.0425 & 0.0330 & 13514 & $2,552.37$ & $796,495,049,575$ \\
\hline 35 & $8 / 11 / 2017$ & 0.0425 & 0.0330 & 13524 & $2,569.64$ & $672,625,779,371$ \\
\hline 36 & $7 / 11 / 2017$ & 0.0425 & 0.0330 & 13504 & $2,555.86$ & $715,937,115,772$ \\
\hline 37 & $6 / 11 / 2017$ & 0.0425 & 0.0330 & 13529 & $2,544.17$ & $879,183,721,590$ \\
\hline 38 & $3 / 11 / 2017$ & 0.0425 & 0.0330 & 13500 & $2,564.72$ & $1,189,221,284,120$ \\
\hline 39 & $2 / 11 / 2017$ & 0.0425 & 0.0330 & 13562 & $2,521.85$ & $718,077,110,510$ \\
\hline 40 & $1 / 11 / 2017$ & 0.0425 & 0.0330 & 13592 & $2,559.29$ & $633,883,338,720$ \\
\hline 41 & $31-10-2017$ & 0.0425 & 0.0358 & 13572 & $2,546.27$ & $952,286,172,410$ \\
\hline 42 & $30-10-2017$ & 0.0425 & 0.0358 & 13580 & $2,515.43$ & $607,213,842,250$ \\
\hline 43 & $27-10-2017$ & 0.0425 & 0.0358 & 13630 & $2,541.03$ & $901,152,423,205$ \\
\hline 44 & $26-10-2017$ & 0.0425 & 0.0358 & 13560 & $2,541.36$ & $855,013,838,730$ \\
\hline 45 & $25-10-2017$ & 0.0425 & 0.0358 & 13570 & $2,546.64$ & $664,658,911,675$ \\
\hline 46 & 24-10-2017 & 0.0425 & 0.0358 & 13529 & $2,509.42$ & $521,352,538,360$ \\
\hline 47 & $23-10-2017$ & 0.0425 & 0.0358 & 13535 & $2,515.81$ & $517,711,218,640$ \\
\hline 48 & 20-10-2017 & 0.0425 & 0.0358 & 13517 & $2,506.33$ & $600,334,788,857$ \\
\hline
\end{tabular}




\begin{tabular}{|c|c|c|c|c|c|c|}
\hline 49 & $19-10-2017$ & 0.0425 & 0.0358 & 13521 & $2,498.95$ & $706,569,229,339$ \\
\hline 50 & $18-10-2017$ & 0.0425 & 0.0358 & 13514 & $2,530.72$ & $597,701,263,550$ \\
\hline 51 & $17-10-2017$ & 0.0425 & 0.0358 & 13490 & $2,528.21$ & $625,676,005,700$ \\
\hline 52 & $16-10-2017$ & 0.0425 & 0.0358 & 13483 & $2,507.68$ & $1,691,522,171,888$ \\
\hline 53 & 13-10-2017 & 0.0425 & 0.0358 & 13508 & $2,488.61$ & $652,521,437,325$ \\
\hline 54 & $12 / 10 / 2017$ & 0.0425 & 0.0358 & 13521 & $2,494.28$ & $798,338,676,250$ \\
\hline 55 & $11 / 10 / 2017$ & 0.0425 & 0.0358 & 13509 & $2,505.81$ & $784,345,872,165$ \\
\hline 56 & $10 / 10 / 2017$ & 0.0425 & 0.0358 & 13491 & $2,527.27$ & $672,348,655,300$ \\
\hline 57 & $9 / 10 / 2017$ & 0.0425 & 0.0358 & 13504 & $2,534.61$ & $612,824,793,100$ \\
\hline 58 & $6 / 10 / 2017$ & 0.0425 & 0.0358 & 13485 & $2,517.13$ & $485,237,576,209$ \\
\hline 59 & $5 / 10 / 2017$ & 0.0425 & 0.0358 & 13483 & $2,522.34$ & $677,080,663,980$ \\
\hline 60 & $4 / 10 / 2017$ & 0.0425 & 0.0358 & 13489 & $2,551.81$ & $534,596,152,775$ \\
\hline 61 & $3 / 10 / 2017$ & 0.0425 & 0.0358 & 13582 & $2,546.26$ & $705,401,355,190$ \\
\hline 62 & $2 / 10 / 2017$ & 0.0425 & 0.0358 & 13499 & $2,534.85$ & $411,220,506,045$ \\
\hline 63 & 29-09-2017 & 0.0425 & 0.0372 & 13492 & $2,498.69$ & $534,987,777,995$ \\
\hline 64 & 28-09-2017 & 0.0425 & 0.0372 & 13464 & $2,503.26$ & $605,250,124,625$ \\
\hline 65 & 27-09-2017 & 0.0425 & 0.0372 & 13384 & $2,527.20$ & $684,602,845,200$ \\
\hline 66 & 26-09-2017 & 0.0425 & 0.0372 & 13348 & $2,496.07$ & $396,863,952,225$ \\
\hline 67 & $25-09-2017$ & 0.0425 & 0.0372 & 13305 & $2,531.31$ & $499,194,582,310$ \\
\hline 68 & 22-09-2017 & 0.0425 & 0.0372 & 13325 & $2,534.87$ & $657,607,751,725$ \\
\hline 69 & 20-09-2017 & 0.0425 & 0.0372 & 13270 & $2,561.17$ & $506,488,059,726$ \\
\hline 70 & $19-09-2017$ & 0.0425 & 0.0372 & 13258 & $2,548.79$ & $640,751,088,750$ \\
\hline 71 & 18-09-2017 & 0.0425 & 0.0372 & 13238 & $2,553.86$ & $495,632,162,145$ \\
\hline 72 & $15-09-2017$ & 0.0425 & 0.0372 & 13261 & $2,540.38$ & $742,703,199,825$ \\
\hline 73 & 14-09-2017 & 0.0425 & 0.0372 & 13239 & $2,541.17$ & $761,317,858,080$ \\
\hline 74 & 13-09-2017 & 0.0425 & 0.0372 & 13209 & $2,520.89$ & $600,874,205,850$ \\
\hline 75 & $12 / 9 / 2017$ & 0.0425 & 0.0372 & 13186 & $2,521.36$ & $499,865,814,600$ \\
\hline 76 & $11 / 9 / 2017$ & 0.0425 & 0.0372 & 13154 & $2,508.33$ & $463,447,661,970$ \\
\hline 77 & 8/9/2017 & 0.0425 & 0.0372 & 13284 & $2,501.97$ & $618,173,562,760$ \\
\hline 78 & $7 / 9 / 2017$ & 0.0425 & 0.0372 & 13331 & $2,486.32$ & $313,310,700,910$ \\
\hline 79 & 6/9/2017 & 0.0425 & 0.0372 & 13337 & $2,485.85$ & $543,260,740,150$ \\
\hline 80 & $5 / 9 / 2017$ & 0.0425 & 0.0372 & 13336 & $2,489.52$ & $545,296,674,473$ \\
\hline 81 & $4 / 9 / 2017$ & 0.0425 & 0.0372 & 13345 & $2,475.11$ & $508,192,520,215$ \\
\hline 82 & 31-08-2017 & 0.0450 & 0.0382 & 13351 & $2,494.61$ & $725,233,297,945$ \\
\hline 83 & 30-08-2017 & 0.0450 & 0.0382 & 13343 & $2,488.46$ & $742,970,552,655$ \\
\hline 84 & 29-08-2017 & 0.0450 & 0.0382 & 13348 & $2,512.88$ & $468,296,610,225$ \\
\hline 85 & 28-08-2017 & 0.0450 & 0.0382 & 13338 & $2,498.92$ & $293,234,576,600$ \\
\hline 86 & $25-08-2017$ & 0.0450 & 0.0382 & 13348 & $2,509.15$ & $575,025,671,325$ \\
\hline 87 & 24-08-2017 & 0.0450 & 0.0382 & 13354 & $2,477.07$ & $447,380,117,256$ \\
\hline 88 & 23-08-2017 & 0.0450 & 0.0382 & 13342 & $2,496.75$ & $527,228,091,693$ \\
\hline 89 & 22-08-2017 & 0.0450 & 0.0382 & 13338 & $2,469.73$ & $583,054,082,500$ \\
\hline 90 & 21-08-2017 & 0.0450 & 0.0382 & 13355 & $2,458.84$ & $579,497,178,660$ \\
\hline 91 & $18-08-2017$ & 0.0450 & 0.0382 & 13368 & $2,518.12$ & $781,255,314,380$ \\
\hline 92 & $16-08-2017$ & 0.0450 & 0.0382 & 13374 & $2,494.19$ & $817,488,980,013$ \\
\hline 93 & $15-08-2017$ & 0.0450 & 0.0382 & 13344 & $2,410.86$ & $534,708,665,875$ \\
\hline
\end{tabular}




\begin{tabular}{|c|c|c|c|c|c|c|}
\hline 94 & $14-08-2017$ & 0.0450 & 0.0382 & 13344 & $2,386.28$ & $501,457,815,300$ \\
\hline 95 & $11 / 8 / 2017$ & 0.0450 & 0.0382 & 13370 & $2,367.87$ & $666,337,534,060$ \\
\hline 96 & $10 / 8 / 2017$ & 0.0450 & 0.0382 & 13338 & $2,391.62$ & $602,848,368,893$ \\
\hline 97 & $9 / 8 / 2017$ & 0.0450 & 0.0382 & 13324 & $2,389.45$ & $926,142,385,400$ \\
\hline 98 & 8/8/2017 & 0.0450 & 0.0382 & 13319 & $2,405.21$ & $560,325,826,590$ \\
\hline 99 & $7 / 8 / 2017$ & 0.0450 & 0.0382 & 13319 & $2,371.07$ & $628,365,770,300$ \\
\hline 100 & $4 / 8 / 2017$ & 0.0450 & 0.0382 & 13324 & $2,406.22$ & $586,965,310,952$ \\
\hline 101 & $3 / 8 / 2017$ & 0.0450 & 0.0382 & 13330 & $2,411.59$ & $686,965,564,110$ \\
\hline 102 & $2 / 8 / 2017$ & 0.0450 & 0.0382 & 13331 & $2,425.69$ & $794,416,800,614$ \\
\hline 103 & $1 / 8 / 2017$ & 0.0450 & 0.0382 & 13318 & $2,413.62$ & $743,097,628,964$ \\
\hline 104 & $31-07-2017$ & 0.0475 & 0.0388 & 13323 & $2,467.16$ & $1,046,068,281,501$ \\
\hline 105 & 28-07-2017 & 0.0475 & 0.0388 & 13326 & $2,498.43$ & $869,241,938,008$ \\
\hline 106 & 27-07-2017 & 0.0475 & 0.0388 & 13315 & $2,489.44$ & $492,416,559,283$ \\
\hline 107 & $26-07-2017$ & 0.0475 & 0.0388 & 13334 & $2,484.46$ & $548,513,829,215$ \\
\hline 108 & $25-07-2017$ & 0.0475 & 0.0388 & 13320 & $2,514.90$ & $630,988,614,600$ \\
\hline 109 & 24-07-2017 & 0.0475 & 0.0388 & 13319 & $2,505.84$ & $898,362,157,585$ \\
\hline 110 & 21-07-2017 & 0.0475 & 0.0388 & 13323 & $2,489.16$ & $686,860,931,190$ \\
\hline 111 & $20-07-2017$ & 0.0475 & 0.0388 & 13320 & $2,518.02$ & $508,194,554,300$ \\
\hline 112 & $19-07-2017$ & 0.0475 & 0.0388 & 13304 & $2,502.37$ & $477,936,317,800$ \\
\hline 113 & $18-07-2017$ & 0.0475 & 0.0388 & 13314 & $2,510.75$ & $484,795,015,360$ \\
\hline 114 & $17-07-2017$ & 0.0475 & 0.0388 & 13313 & $2,520.01$ & $532,838,829,760$ \\
\hline 115 & $14-07-2017$ & 0.0475 & 0.0388 & 13347 & $2,525.14$ & $493,544,222,226$ \\
\hline 116 & $13-07-2017$ & 0.0475 & 0.0388 & 13342 & $2,527.10$ & $494,994,513,085$ \\
\hline 117 & $12 / 7 / 2017$ & 0.0475 & 0.0388 & 13368 & $2,520.66$ & $413,991,537,629$ \\
\hline 118 & $11 / 7 / 2017$ & 0.0475 & 0.0388 & 13387 & $2,491.12$ & $385,645,966,090$ \\
\hline 119 & $10 / 7 / 2017$ & 0.0475 & 0.0388 & 13408 & $2,483.97$ & $359,884,545,075$ \\
\hline 120 & 7/7/2017 & 0.0475 & 0.0388 & 13397 & $2,507.09$ & $559,928,761,790$ \\
\hline 121 & $6 / 7 / 2017$ & 0.0475 & 0.0388 & 13364 & $2,533.27$ & $562,968,303,700$ \\
\hline 122 & $5 / 7 / 2017$ & 0.0475 & 0.0388 & 13349 & $2,519.38$ & $633,370,132,720$ \\
\hline 123 & $4 / 7 / 2017$ & 0.0475 & 0.0388 & 13386 & $2,545.51$ & $620,476,718,734$ \\
\hline 124 & 3/7/2017 & 0.0475 & 0.0388 & 13325 & $2,577.85$ & $781,392,539,628$ \\
\hline 125 & 22-06-2017 & 0.0475 & 0.0437 & 13319 & $2,554.38$ & $702,396,854,280$ \\
\hline 126 & 21-06-2017 & 0.0475 & 0.0437 & 13301 & $2,557.57$ & $781,928,639,543$ \\
\hline 127 & 20-06-2017 & 0.0475 & 0.0437 & 13297 & $2,547.83$ & $655,651,161,580$ \\
\hline 128 & 19-06-2017 & 0.0475 & 0.0437 & 13286 & $2,529.47$ & $476,104,152,090$ \\
\hline 129 & $16-06-2017$ & 0.0475 & 0.0437 & 13298 & $2,528.00$ & $952,716,650,700$ \\
\hline 130 & $15-06-2017$ & 0.0475 & 0.0437 & 13282 & $2,546.94$ & $537,368,526,035$ \\
\hline 131 & 14-06-2017 & 0.0475 & 0.0437 & 13286 & $2,546.86$ & $630,494,813,000$ \\
\hline 132 & 13-06-2017 & 0.0475 & 0.0437 & 13294 & $2,517.06$ & $630,851,338,691$ \\
\hline 133 & $12 / 6 / 2017$ & 0.0475 & 0.0437 & 13292 & $2,509.13$ & $373,766,037,712$ \\
\hline 134 & 9/6/2017 & 0.0475 & 0.0437 & 13292 & $2,508.27$ & $623,983,472,670$ \\
\hline 135 & 8/6/2017 & 0.0475 & 0.0437 & 13316 & $2,518.72$ & $797,095,194,240$ \\
\hline 136 & $7 / 6 / 2017$ & 0.0475 & 0.0437 & 13307 & $2,513.67$ & $312,953,606,790$ \\
\hline 137 & 6/6/2017 & 0.0475 & 0.0437 & 13285 & $2,513.91$ & $404,548,456,075$ \\
\hline 138 & $5 / 6 / 2017$ & 0.0475 & 0.0437 & 13287 & $2,519.08$ & $344,610,404,210$ \\
\hline
\end{tabular}




\begin{tabular}{|c|c|c|c|c|c|c|}
\hline 139 & $2 / 6 / 2017$ & 0.0475 & 0.0437 & 13311 & $2,514.78$ & $575,615,246,135$ \\
\hline 140 & $31-05-2017$ & 0.0475 & 0.0433 & 13321 & $2,517.10$ & $1,285,892,423,575$ \\
\hline 41 & $30-05-2017$ & 0.0475 & 0.0433 & 13336 & $2,492.24$ & $519,895,329,850$ \\
\hline 42 & 29-05-2017 & 0.0475 & 0.0433 & 13312 & $2,509.10$ & $504,145,204,795$ \\
\hline 143 & $26-05-2017$ & 0.0475 & 0.0433 & 13295 & $2,523.64$ & $514,106,143,745$ \\
\hline 44 & 24-05-2017 & 0.0475 & 0.0433 & 13316 & $2,533.59$ & $851,442,304,405$ \\
\hline 145 & 23-05-2017 & 0.0475 & 0.0433 & 13296 & $2,543.20$ & $689,696,214,450$ \\
\hline 46 & $22-05-2017$ & 0.0475 & 0.0433 & 13297 & $2,516.22$ & $905,039,409,660$ \\
\hline 147 & $19-05-2017$ & 0.0475 & 0.0433 & 13410 & $2,581.04$ & $726,115,530,265$ \\
\hline 48 & $18-05-2017$ & 0.0475 & 0.0433 & 13343 & $2,518.05$ & $671,160,661,010$ \\
\hline 149 & $17-05-2017$ & 0.0475 & 0.0433 & 13306 & $2,494.47$ & $640,458,962,100$ \\
\hline 150 & $16-05-2017$ & 0.0475 & 0.0433 & 13298 & $2,494.36$ & $383,703,480,050$ \\
\hline 51 & $15-05-2017$ & 0.0475 & 0.0433 & 13319 & $2,508.82$ & $437,720,400,873$ \\
\hline 152 & $12 / 5 / 2017$ & 0.0475 & 0.0433 & 13340 & $2,494.69$ & $612,454,631,450$ \\
\hline 153 & $10 / 5 / 2017$ & 0.0475 & 0.0433 & 13355 & $2,479.22$ & $603,470,257,963$ \\
\hline 154 & 9/5/2017 & 0.0475 & 0.0433 & 13317 & $2,482.20$ & $676,909,072,686$ \\
\hline 155 & $8 / 5 / 2017$ & 0.0475 & 0.0433 & 13324 & $2,459.60$ & $634,470,750,400$ \\
\hline 156 & $5 / 5 / 2017$ & 0.0475 & 0.0433 & 13339 & $2,483.57$ & $633,258,471,868$ \\
\hline 157 & $4 / 5 / 2017$ & 0.0475 & 0.0433 & 13330 & $2,461.25$ & $563,865,072,432$ \\
\hline 158 & $3 / 5 / 2017$ & 0.0475 & 0.0433 & 13297 & $2,452.27$ & $501,270,520,680$ \\
\hline 159 & 2/5/2017 & 0.0475 & 0.0433 & 13316 & $2,436.86$ & $525,280,237,946$ \\
\hline 160 & $28-04-2017$ & 0.0475 & 0.0417 & 13327 & $2,433.79$ & $687,688,956,545$ \\
\hline 161 & 27-04-2017 & 0.0475 & 0.0417 & 13299 & $2,463.51$ & $1,102,723,436,096$ \\
\hline 162 & $26-04-2017$ & 0.0475 & 0.0417 & 13278 & $2,457.55$ & $547,106,933,355$ \\
\hline 163 & $25-04-2017$ & 0.0475 & 0.0417 & 13296 & $2,440.90$ & $490,534,986,755$ \\
\hline 164 & $21-04-2017$ & 0.0475 & 0.0417 & 13320 & $2,438.36$ & $675,552,513,870$ \\
\hline 165 & 20-04-2017 & 0.0475 & 0.0417 & 13328 & $2,428.26$ & $460,799,529,604$ \\
\hline 166 & $18-04-2017$ & 0.0475 & 0.0417 & 13299 & $2,442.64$ & $402,060,040,702$ \\
\hline 167 & $17-04-2017$ & 0.0475 & 0.0417 & 13255 & $2,434.05$ & $509,094,669,500$ \\
\hline 168 & $13-04-2017$ & 0.0475 & 0.0417 & 13264 & $2,430.34$ & $251,069,780,846$ \\
\hline 169 & $12 / 4 / 2017$ & 0.0475 & 0.0417 & 13298 & $2,438.49$ & $624,053,083,695$ \\
\hline 170 & $11 / 4 / 2017$ & 0.0475 & 0.0417 & 13282 & $2,428.20$ & $384,147,896,662$ \\
\hline 171 & $10 / 4 / 2017$ & 0.0475 & 0.0417 & 13323 & $2,450.48$ & $340,773,671,025$ \\
\hline 172 & $7 / 4 / 2017$ & 0.0475 & 0.0417 & 13341 & $2,453.09$ & $356,696,379,330$ \\
\hline 173 & $6 / 4 / 2017$ & 0.0475 & 0.0417 & 13327 & $2,464.74$ & $419,116,648,725$ \\
\hline 174 & $5 / 4 / 2017$ & 0.0475 & 0.0417 & 13329 & $2,472.02$ & $759,136,717,890$ \\
\hline 175 & $4 / 4 / 2017$ & 0.0475 & 0.0417 & 13326 & $2,458.29$ & $396,896,084,243$ \\
\hline 176 & $3 / 4 / 2017$ & 0.0475 & 0.0417 & 13324 & $2,442.21$ & $679,208,832,080$ \\
\hline 177 & $31-03-2017$ & 0.0475 & 0.0361 & 13321 & $2,404.67$ & $868,052,467,620$ \\
\hline 178 & 29-03-2017 & 0.0475 & 0.0361 & 13316 & $2,438.33$ & $514,532,330,990$ \\
\hline 179 & 24-03-2017 & 0.0475 & 0.0361 & 13323 & $2,417.76$ & $406,629,366,090$ \\
\hline 180 & 23-03-2017 & 0.0475 & 0.0361 & 13314 & $2,408.93$ & $381,016,983,840$ \\
\hline 181 & 22-03-2017 & 0.0475 & 0.0361 & 13329 & $2,408.71$ & $764,538,651,435$ \\
\hline 182 & 21-03-2017 & 0.0475 & 0.0361 & 13332 & $2,432.02$ & $661,496,363,420$ \\
\hline 183 & 20-03-2017 & 0.0475 & 0.0361 & 13335 & $2,434.24$ & $368,945,208,770$ \\
\hline
\end{tabular}




\begin{tabular}{|c|c|c|c|c|c|c|}
\hline 184 & 17-03-2017 & 0.0475 & 0.0361 & 13308 & $2,441.17$ & $1,897,304,574,274$ \\
\hline 185 & $16-03-2017$ & 0.0475 & 0.0361 & 13329 & $2,444.83$ & $560,200,107,212$ \\
\hline 186 & 15-03-2017 & 0.0475 & 0.0361 & 13342 & $2,400.93$ & $391,338,306,470$ \\
\hline 187 & 14-03-2017 & 0.0475 & 0.0361 & 13336 & $2,406.01$ & $7,125,759,839,535$ \\
\hline 188 & 13-03-2017 & 0.0475 & 0.0361 & 13375 & $2,400.63$ & $390,453,665,020$ \\
\hline 189 & $10 / 3 / 2017$ & 0.0475 & 0.0361 & 13360 & $2,390.80$ & $406,713,605,410$ \\
\hline 190 & 9/3/2017 & 0.0475 & 0.0361 & 13364 & $2,390.67$ & $375,267,986,629$ \\
\hline 191 & $8 / 3 / 2017$ & 0.0475 & 0.0361 & 13393 & $2,394.61$ & $368,643,687,347$ \\
\hline 192 & $7 / 3 / 2017$ & 0.0475 & 0.0361 & 13373 & $2,383.44$ & $498,175,119,835$ \\
\hline 193 & $6 / 3 / 2017$ & 0.0475 & 0.0361 & 13340 & $2,392.66$ & $417,651,012,890$ \\
\hline 194 & $3 / 3 / 2017$ & 0.0475 & 0.0361 & 13350 & $2,393.67$ & $639,499,698,132$ \\
\hline 195 & $2 / 3 / 2017$ & 0.0475 & 0.0361 & 13364 & $2,414.71$ & $893,109,811,152$ \\
\hline 196 & $1 / 3 / 2017$ & 0.0475 & 0.0361 & 13375 & $2,360.90$ & $371,461,809,714$ \\
\hline 197 & 28-02-2017 & 0.0475 & 0.0361 & 13361 & $2,374.98$ & $379,223,618,425$ \\
\hline 198 & 27-02-2017 & 0.0475 & 0.0361 & 13361 & $2,388.05$ & $295,989,761,553$ \\
\hline 199 & 24-02-2017 & 0.0475 & 0.0383 & 13347 & $2,374.99$ & $371,202,879,335$ \\
\hline 200 & 23-02-2017 & 0.0475 & 0.0383 & 13339 & $2,360.45$ & $417,143,226,153$ \\
\hline 201 & 22-02-2017 & 0.0475 & 0.0383 & 13336 & $2,355.23$ & $456,725,993,925$ \\
\hline 202 & 21-02-2017 & 0.0475 & 0.0383 & 13360 & $2,335.64$ & $336,238,328,777$ \\
\hline 203 & 20-02-2017 & 0.0475 & 0.0383 & 13356 & $2,339.40$ & $283,247,875,215$ \\
\hline 204 & $17-02-2017$ & 0.0475 & 0.0383 & 13370 & $2,349.38$ & $327,174,123,130$ \\
\hline 205 & $16-02-2017$ & 0.0475 & 0.0383 & 13352 & $2,354.82$ & $463,546,575,425$ \\
\hline 206 & $14-02-2017$ & 0.0475 & 0.0383 & 13328 & $2,353.07$ & $379,795,660,910$ \\
\hline 207 & 13-02-2017 & 0.0475 & 0.0383 & 13329 & $2,363.75$ & $421,790,678,785$ \\
\hline 208 & 10/2/2017 & 0.0475 & 0.0383 & 13330 & $2,364.79$ & $477,618,328,328$ \\
\hline 209 & 9/2/2017 & 0.0475 & 0.0383 & 13330 & $2,349.53$ & $417,676,323,720$ \\
\hline 210 & $8 / 2 / 2017$ & 0.0475 & 0.0383 & 13318 & $2,362.02$ & $376,171,172,940$ \\
\hline 211 & $7 / 2 / 2017$ & 0.0475 & 0.0383 & 13308 & $2,368.33$ & $454,981,394,723$ \\
\hline 212 & $6 / 2 / 2017$ & 0.0475 & 0.0383 & 13337 & $2,376.23$ & $478,972,240,443$ \\
\hline 213 & $3 / 2 / 2017$ & 0.0475 & 0.0383 & 13322 & $2,357.25$ & $485,116,007,856$ \\
\hline 214 & 2/2/2017 & 0.0475 & 0.0383 & 13329 & $2,343.30$ & $512,496,235,918$ \\
\hline 215 & $1 / 2 / 2017$ & 0.0475 & 0.0383 & 13362 & 2,339.05 & $298,759,849,742$ \\
\hline 216 & 30-01-2017 & 0.0475 & 0.0383 & 13374 & $2,342.44$ & $286,328,937,260$ \\
\hline 217 & 27-01-2017 & 0.0475 & 0.0383 & 13349 & $2,359.87$ & $354,625,442,054$ \\
\hline 218 & $26-01-2017$ & 0.0475 & 0.0349 & 13343 & $2,381.04$ & $187,719,200,134$ \\
\hline 219 & $25-01-2017$ & 0.0475 & 0.0349 & 13335 & $2,380.15$ & $356,624,995,140$ \\
\hline 220 & 24-01-2017 & 0.0475 & 0.0349 & 13359 & $2,374.10$ & $395,894,754,405$ \\
\hline 221 & 23-01-2017 & 0.0475 & 0.0349 & 13325 & $2,343.51$ & $382,899,464,410$ \\
\hline 222 & 20-01-2017 & 0.0475 & 0.0349 & 13340 & $2,332.77$ & $280,964,965,375$ \\
\hline 223 & $19-01-2017$ & 0.0475 & 0.0349 & 13330 & $2,345.22$ & $574,972,989,809$ \\
\hline 224 & $18-01-2017$ & 0.0475 & 0.0349 & 13372 & $2,352.63$ & $309,828,587,085$ \\
\hline 225 & $17-01-2017$ & 0.0475 & 0.0349 & 13382 & $2,335.55$ & $246,305,721,070$ \\
\hline 226 & $16-01-2017$ & 0.0475 & 0.0349 & 13376 & $2,349.48$ & $334,189,607,713$ \\
\hline 227 & 13-01-2017 & 0.0475 & 0.0349 & 13328 & $2,338.45$ & $509,095,023,240$ \\
\hline 228 & $12 / 1 / 2017$ & 0.0475 & 0.0349 & 13381 & $2,353.16$ & $416,447,865,031$ \\
\hline
\end{tabular}




$\begin{array}{rrrrrrr}229 & 11 / 1 / 2017 & 0.0475 & 0.0349 & 13354 & 2,366.79 & 318,940,962,880 \\ 230 & 10 / 1 / 2017 & 0.0475 & 0.0349 & 13308 & 2,371.25 & 352,567,735,595 \\ 231 & 9 / 1 / 2017 & 0.0475 & 0.0349 & 13288 & 2,379.46 & 345,427,369,605 \\ 232 & 6 / 1 / 2017 & 0.0475 & 0.0349 & 13327 & 2,394.54 & 250,289,232,990 \\ 233 & 5 / 1 / 2017 & 0.0475 & 0.0349 & 13320 & 2,392.97 & 407,355,350,795 \\ 234 & 4 / 1 / 2017 & 0.0475 & 0.0349 & 13385 & 2,359.81 & 390,034,614,475 \\ 235 & 3 / 1 / 2017 & 0.0475 & 0.0349 & 13347 & 2,314.68 & 195,457,817,900\end{array}$

Berikut ini peneliti sajikan kerangka berpikir penelitian guna menguji hipotesis :

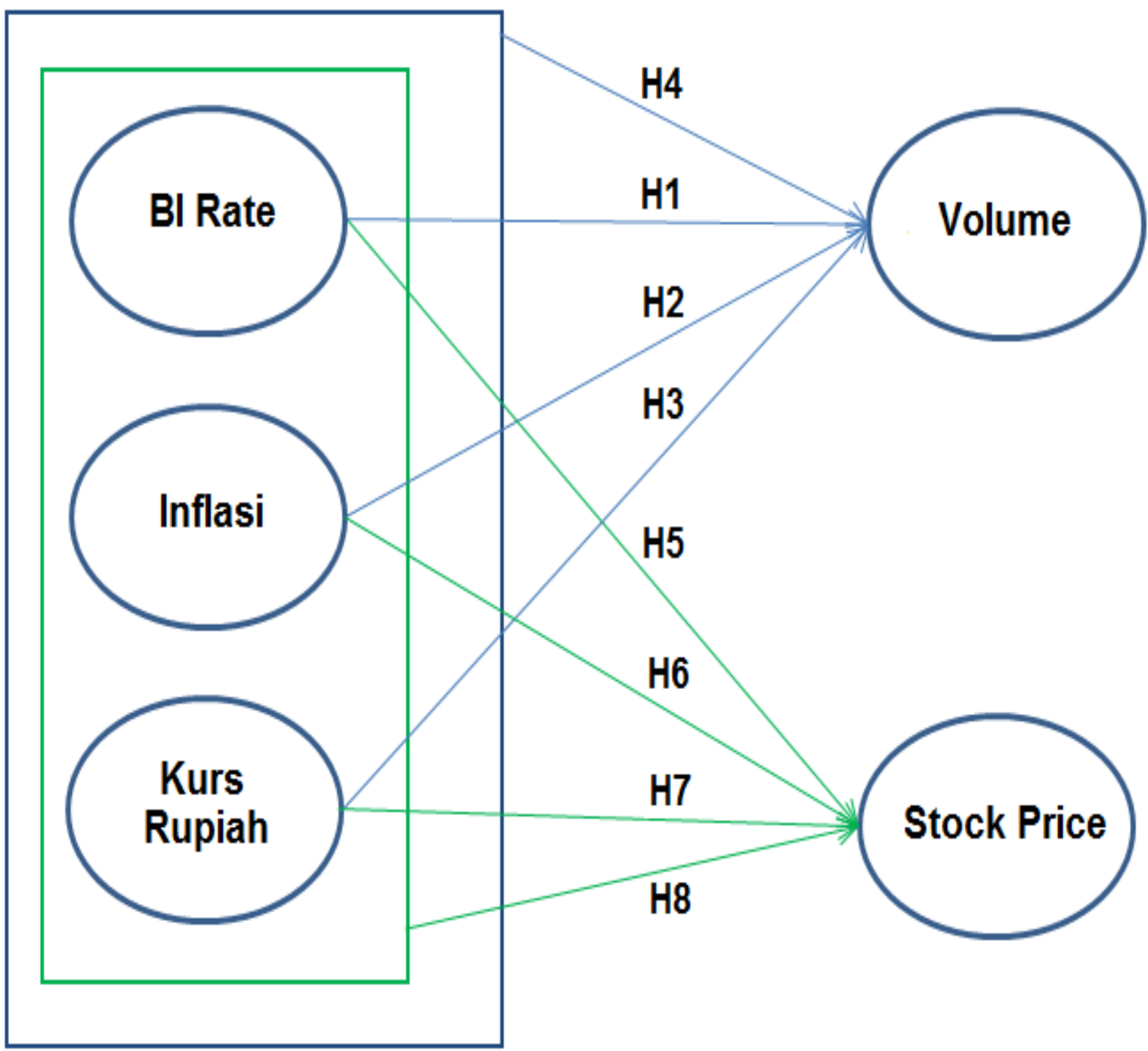

Gambar 1. Kerangka Berpikir Penelitian

Untuk melihat fenomena pergerakan harga saham saham dari Index Consumer Goods, peneliti menyajikan dalam gambar berikut ini : 


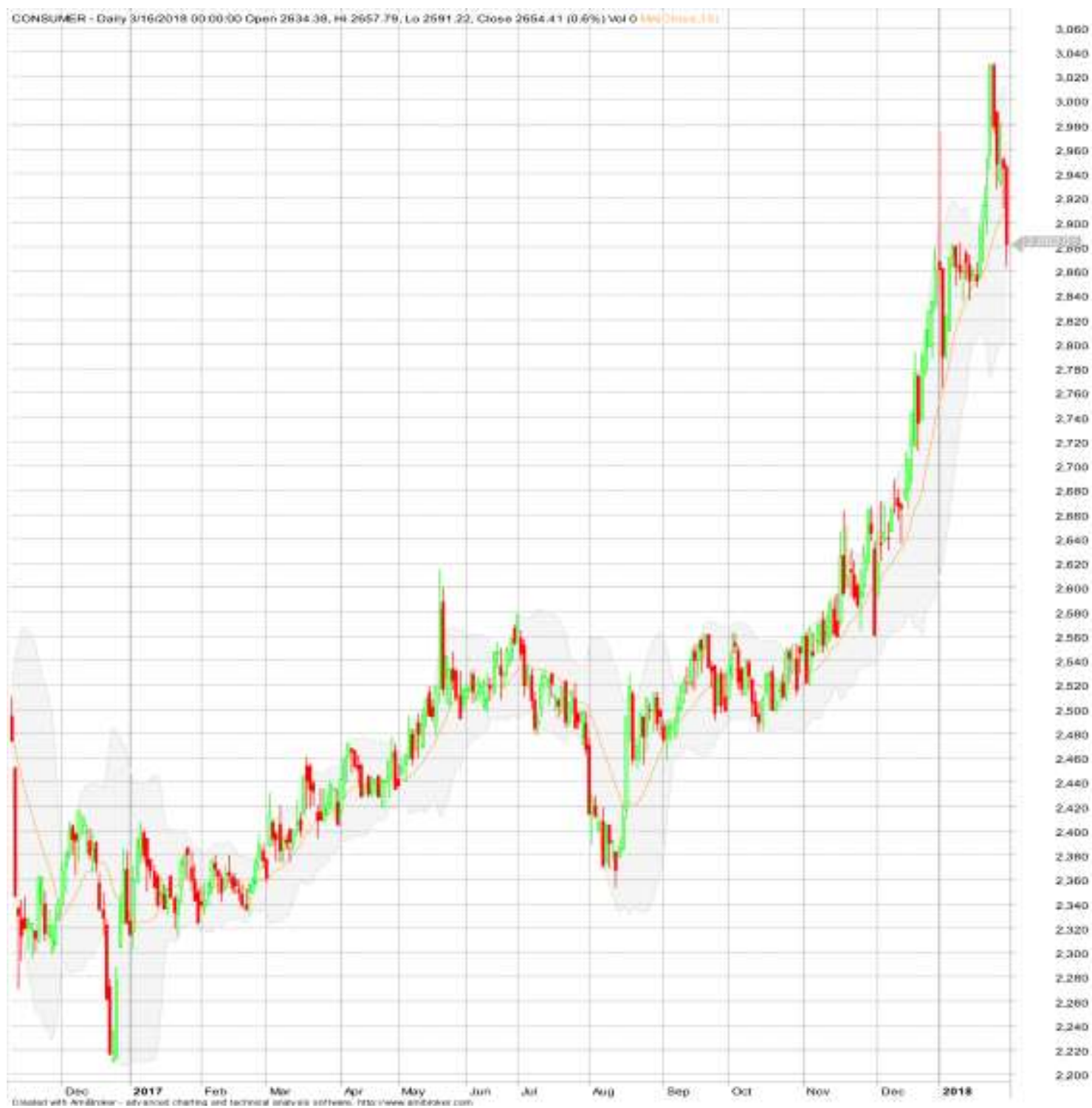

Gambar 2. Pergerakan Harga Saham Index Consumer Goods Selama tahun 2107

Model 1 dalam penelitian disajikan sebagai berikut :

Dependent Variable: VOL

Method: Least Squares

Date: 03/14/18 Time: 09:11

Sample: 1235

Included observations: 235

\begin{tabular}{crrrr}
\hline \hline Variable & Coefficient & Std. Error & t-Statistic & Prob. \\
\hline \hline C & $-1.30 \mathrm{E}+13$ & $7.39 \mathrm{E}+12$ & -1.753247 & 0.0809 \\
BI & $-1.94 \mathrm{E}+13$ & $2.08 \mathrm{E}+13$ & -0.932908 & 0.3518 \\
INF & $8.12 \mathrm{E}+12$ & $1.39 \mathrm{E}+13$ & 0.583268 & 0.5603 \\
KURS & $1.06 \mathrm{E}+09$ & $4.99 \mathrm{E}+08$ & 2.125002 & 0.0346 \\
\hline \hline
\end{tabular}

R-squared 0.057534 Mean dependent var $6.59 \mathrm{E}+11$


Adjusted R-squared

0.045295 S.D. dependent var

$5.10 \mathrm{E}+11$

$6.01 \mathrm{E}+25$

$-6666.469$

4.700591

0.003316
Akaike info criterion

Schwarz criterion

Hannan-Quinn criter.

Durbin-Watson stat
$5.22 \mathrm{E}+11$

56.76995

56.82883

56.79369

1.887370

Prob(F-statistic)

Estimation Command:

$=========================$

LS VOL C BI INF KURS

Estimation Equation:

$=======================$
$\mathrm{VOL}=\mathrm{C}(1)+\mathrm{C}(2)^{*} \mathrm{BI}+\mathrm{C}(3)^{*} \mathrm{INF}+\mathrm{C}(4)^{*} \mathrm{KURS}$

Substituted Coefficients:

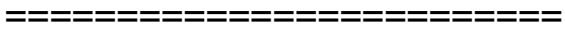

VOL $=-1.29555633019 \mathrm{e}+13-1.93831976095 \mathrm{e}+13^{*} \mathrm{BI}+8.11585706683 \mathrm{e}+12^{*} \mathrm{INF}+$ $1060223547.99 *$ KURS

Model 2 dalam penelitian disajikan sebagai berikut :

Dependent Variable: PRICE

Method: Least Squares

Date: 03/18/18 Time: 11:16

Sample: 1235

Included observations: 235

\begin{tabular}{crlll}
\hline \hline \multicolumn{1}{c}{ Variable } & Coefficient & Std. Error & t-Statistic & Prob. \\
\hline C & -3661.367 & 929.1578 & -3.940523 & 0.0001 \\
BI & -25688.32 & 2612.540 & -9.832700 & 0.0000 \\
INF & 16783.14 & 1749.616 & 9.592469 & 0.0000 \\
KURS & 0.499573 & 0.062736 & 7.963138 & 0.0000 \\
\hline \hline R-squared & 0.600656 & Mean dependent var & 2490.693 \\
Adjusted R-squared & 0.595470 & S.D. dependent var & 100.8176 \\
S.E. of regression & 64.12273 & Akaike info criterion & 11.17635 \\
Sum squared resid & 949808.3 & Schwarz criterion & 11.23524 \\
Log likelihood & -1309.221 & Hannan-Quinn criter. & 11.20009 \\
F-statistic & 115.8162 & Durbin-Watson stat & 0.190036 \\
Prob(F-statistic) & 0.000000 & & & \\
\hline
\end{tabular}

Estimation Command:

$==================+=$
LS PRICE C BI INF KURS

Estimation Equation:

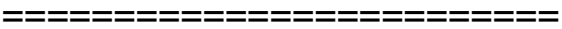

PRICE $=\mathrm{C}(1)+\mathrm{C}(2)^{*} \mathrm{BI}+\mathrm{C}(3)^{*} \mathrm{INF}+\mathrm{C}(4)^{*} \mathrm{KURS}$

Substituted Coefficients:

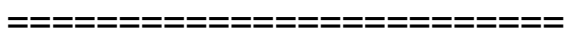

PRICE $=-3661.36746646-25688.3231165^{\star} \mathrm{BI}+16783.1363289^{*} \mathrm{INF}+$ $0.499572714099 * K U R S$ 


\section{Pembahasan}

Hasil penelitian menunjukkan bahwa secara parsial BI Rate, Inflasi tidak berpengaruh terhadap Volume Perdagangan Index Consumer Goods, dengan nilai signifikansi untuk masing-masing variable adalah 0.3518 dan 0.5603, sedangkan Kurs Rupiah memiliki pegaruh yang signifikan terhadap Volume Perdagangan Index Consumer Goods dengan nilai signifikansi 0.0346 . Secara bersama-sama variable makroekonomi BI Rate, Inflasi dan Kurs Rupiah berpengaruh sangat signifikan terhadap Volume Perdagangan Index Consumer Goods, dengan nilai signifikansi sebesar 0.003316. Hal ini sejalan dengan penelitian yang dilakukan oleh Tarun Chordia; Richard Roll; Avanidhar Subrahmanyam (2001) bahwa variable makroekonomi seperti inflasi dan suku bunga mempengaruhi likuiditas pasar. Sedangkan hasil penelitian dengan dependen variable harga saham, menunjukkan bahwa BI Rate, Inflasi dan Kurs Rupiah secara parsial maupun bersama-sama berpengaruh sangat signifikan terhadap Harga Saham Index Consumer Goods. Hal ini sesuai Teori Arbitrage Pricing Stephen Ross (1976) dan sesuai dengan penelitian yang pernah dilakukan oleh dan Chen, Roll dan Ross (1986) dimana faktor makroekonomi berpengaruh terhadap harga saham. Rekomendasi hasil dari penelitian dapat digunakan bagi investor dan masyarakat agar memperhatikan variable makroekonomi dalam pengambilan keputusan investasi pasar modal, khususnya investasi portofolio saham. Saran bagi penelitan selanjutnya perlu dilakukan peneltian lebih lanjut mengenai faktor-faktor yang mempengaruhi Volume Perdagangan Saham, hal ini dapat dilihat dari nilai $\mathrm{R}$ Square yang diperoleh dari hasil penelitian sebesar 0.057534 , yang berarti bahwa variable makroekonomi memberikan kontribusi yang sangat lemah terhadap Volume Perdagangan Saham, hanya satu variable yang signifikan yaitu Kurs Rupiah.

\section{G. Kesimpulan}

1. BI Rate tidak berpengaruh terhadap Volume Perdagangan Saham Index Consumer Goods

2. Inflasi tidak berpengaruh terhadap Volume Perdagangan Saham Index Consumer Goods

3. Kurs Rupiah berpengaruh signifikan terhadap Volume Perdagangan Saham Index Consumer Goods

4. BI Rate, Inflasi dan Kurs Rupiah secara bersama-sama berpengaruh sangat signifikan terhadap Volume Perdagangan Saham Index Consumer Goods

5. BI Rate berpengaruh sangat signifikan terhadap Harga Saham Index Consumer Goods

6. Inflasi berpengaruh sangat signifikan terhadap Harga Saham Index Consumer Goods

7. Kurs Rupiah berpengaruh sangat signifikan terhadap Harga Saham Index Consumer Goods

8. BI Rate, Inflasi dan Kurs Rupiah secara bersama-sama berpengaruh sangat signifikan terhadap Harga Saham Index Consumer Goods 


\section{H. Daftar Pustaka}

Bambang Juanda, Junaidi. 2012. Ekonometrika Deret Waktu Teori dan Aplikasi,

Penerbit PT. Penerbit IPB Press, Kampus IPB Taman Kencana Bogor.

Bambang Juanda. 2009. Ekonometrika: Pemodelan dan Pendugaan, IPB Press, Bogor.

Bambang Widjanarko Otok, Suryo Guritno dan Subanar. 2006.

Eduardus Tandelilin. 2010. Portofolio dan Investasi Teori dan Aplikasi Edisi Pertama, Penerbit Kanisius (Anggota IKAPI), Yogyakarta.

Gujarati, N. Damodar, dan Porter, C. Dawn. 2010. Basic Econometrics, $5^{\text {th }}$ edition, The McGraw-Hill Companies.

Jogiyanto Hartono. 2013. Teori Portofolio dan Analisis Investasi, Edisi Kedelapan, BPFE-Yogyakarta.

Nai-Fu Chen; Richard Roll; Stephen A. Ross. 1986. Economic Forces and the Stock Market. The Journal of Business, Vol. 59, No.3 (Jul., 1986), 383-403.

Nardi Sunardi (2017) Determinan Kebijakan Utang Serta Implikasinya terhadap Kinerja Perusahaan (Perusahaan yang tergabung dalam indeks LQ.45 yang terdaftar di Bursa Efek Indonesia Tahun 2011- 2015) Jurnal Sekuritas, Vol. 1, No.1 / September 2017 Universitas Pamulang.

Nardi Sunardi, Aceng Abdul Hamid, Lativa, Abdul Kadim, Natanael Tulus (2018) Determinant Of Cost Efficiency And It's Implications For Companies Performance Incorporated In The Lq.45 Index Listing In Idx For The Period of 2011-2016, International Journal of Applied Business and Economic Research,. Volume 16, Number 1, 2018, ISSN : $0972-7302$

Rasmiah Ahmad Abu Mousa. 2016. The Impact of Macroeconomic Variables on Amman Stock Exchange (ASE) Liquidity Measurements. Research Journal of Finance and Accounting. ISSN 2222-1697 (Paper) ISSN 2222-2847 (Online). Vol.7, No.20, 2016

Stephen A. Ross. 1976. The Arbitrage Theory of Capital Asset Pricing. Journal Of Economic Theory 13, 341-360 (1976)

Sugiyono. 2013. Metode Penelitian Kuantitatif, Kualitatif dan Kombinasi (Mixed Methods). Cetakan ke-4, Penerbit Alfabeta, Bandung.

Tarun Chordia; Richard Roll; Avanidhar Subrahmanyam. 2001. Market Liquidity and Trading Activity. The Journal of Finance, Vol. 56, No. 2. (Apr., 2001), pp. 501530.

Woon Gyu Choi, David Cook. 2005. Stock Market Liquidity and the Macroeconomy. International Monetary Fund Working Paper No. 05/6.

www.bi.go.id

www.duniainvestasi.com

www.idx.co.id 